\title{
STRATEGI PENERAPAN SISTEM COMPUTER BASED-TEST (CBT) PADA SELEKSI MAHASISWA BARU DENGAN METODE WARD AND PEPPARD
}

(Studi kasus di STIKES Muhammadiyah Samarinda)

\author{
Wawan Joko Pranoto ${ }^{1}$, Agus Widodo ${ }^{2}$ \\ Program Studi Teknik Informatika ,Fakultas Ilmu Komputer, Universitas Bina Nusantara \\ Jln. Kebon Jeruk Raya No. 27 RT.1/RW.9, Kebon Jeruk, Jakarta Barat, 11530 Indonesia \\ E-mail: 'wwn_jp@yahoo.co.id, ${ }^{2}$ awd2098@gmail.com
}

\begin{abstract}
Abstrak
Sekolah Tinggi Ilmu Kesehatan (STIKES) Muhammadiyah Samarinda saat ini memiliki sistem informasi sebagai pendukung kerja operasional namun tanpa disertai perencanaan yang matang mengenai arahan visi dan misi perguruan tinggi itu sendiri. Pemanfaatan sistem informasi di STIKES Muhammadiyah Samarinda khususnya sistem Computer Based-Test(CBT) saat ini hanya sebagai alat pendukung pengolahan data dan seleksi mahasiswa baru, belum digunakan sebagai sistem informasi yang strategis. Adapun metode analisis yang digunakan dalam penelitian ini adalah metode Ward \& Peppard, yang meliputi metode analisis SWOT untuk menganalisis lingkungan internal bisnis, analisis Porter's five forces untuk menganalisis lingkungan eksternal bisnis, analisis gap untuk membandingkan system informasi saat ini dengan perencanaan sistem informasi yang akan datang, dan analisis Mc Farlan untuk mengklasifikasikan portofolio aplikasi sistem informasi mendatang. Dari setiap solusi strategi penerapan sistem Computer-Based Test (CBT) dipetakan menjadi usulan portofolio aplikasi di masa mendatang, usulan perubahan teknologi berupa hardware dan software, usulan penambahan infrastruktur jaringan dan usulan kebutuhan sumber daya manusia.
\end{abstract}

Kata kunci : Perencanaan Strategis Sistem informasi, SWOT, Five Forces Porter, portofolio Mc farlan, Penerimaan Mahasiswa Baru.

\begin{abstract}
:
College of Health Sciences (STIKES) Muhammadiyah, Samarinda currently has information systems to support the operational work but still lack of thorough planning regarding the direction of the vision and mission of the college itself. The use of information systems in STIKES Muhammadiyah Samarinda particularly Computer Based Test (CBT) systems is currently limited only as a tool to support data processing and selection of new students. It has not been used as a of strategic information system yet. The method of analysis used in this study is the Ward \&Peppard, which utilises SWOT analytical method to analyze the internal business environment, five forces analysis to analyze the external environment of business, gap analysis system to compare the current and the future information systems, and Mc Farlan method to classify the information system application portfolio. Each solution of the implementation strategy for the Computer-Based Test (CBT) system is then mapped into the proposed portfolio of applications in the future, the proposed changes in technology in the form of hardware and software, the proposed additional network infrastructure and the proposed human resource requirements.
\end{abstract}

Keywords: Strategic Planning, Information Systems, SWOT, Porter's Five Forces, Mc Farlan's portfolio, Admissions 


\section{PENDAHULUAN}

Penerimaan mahasiswa baru merupakan peristiwa yang penting bagi hampir seluruh Perguruan Tinggi. Peristiwa yang berulang tiap tahun ini dapat dikatakan sebagai titik awal proses pencarian sumber daya yang berkualitas, yaitu calon mahasiswa. Dengan menerima calon mahasiswa yang berkompeten maka akan dapat menunjang mutu dan kualitas Perguruan Tinggi itu sendiri. Banyaknya jumlah calon mahasiswa yang mendaftar berbanding dengan kapasitas yang disediakan oleh Perguruan Tinggi adalah masalah yang umum. Tentu saja hal ini sudah dipikirkan oleh Perguruan Tinggi dengan mengadakan ujian untuk seleksi penerimaan mahasiswa baru.

Dalam suatu institusi pendidikan terdapat berbagai macam ujian maupun tes sebagai syarat kelulusan penerimaan mahasiswa baru bagi calon peserta didik seperti antara lain tes kesehatan, akademik, psikotes maupun tes penunjang lainnya untuk meminimalisir terjadinya ketimpangan pada saat calon peserta didik tersebut diterima dan disahkan sebagai peserta didik dalam institusi pendidikan tersebut, oleh karena hal itu suatu institusi pendidikan khususnya Sekolah Tinggi Ilmu Kesehatan (STIKES) Muhammadiyah Samarinda menerapkan sistem Computer-Based Test (CBT).

Pemanfatan sistem Computer-Based Test (CBT) merupakan jawaban dari permasalahan yang terjadi jika dilakukan secara konvensional. Cara konvensional adalah butuh waktu yang tidak sedikit dalam mengolah ratusan hingga ribuan data pendaftar (calon peserta didik) beserta hasil ujian, selain kurang efektif cara tersebut juga kurang efisien karena membutuhkan lebih banyak tenaga kerja ahli untuk menghindari kesalahan koreksi hasil jawaban.

Perencanaan Strategis Sistem Informasi di Perguruan Tinggi diperlukan agar sebuah Perguruan Tinggi penyelenggara jasa pendidikan dapat mengenali target terbaik untuk melakukan proses perencanaan, pembuatan, pengembangan dan penerapan sistem informasi manajemen dan menolong untuk memaksimalkan hasil dari investasi pada bidang teknologi informasi dalam hal ini sistem Computer-Based Test (CBT) pada seleksi mahasiswa baru . Sebuah sistem informasi yang dibuat berdasarkan Perancangan Strategis Sistem Informasi yang baik, akan membantu sebuah pimpinan perguruan tinggi dalam pengambilan keputusan untuk melakukan rencana pengembangan dan merealisasikan pencapaian dari Perguruan Tingginya. Dalam dunia pendidikan saat ini, penerapan dari teknologi informasi untuk menentukan strategi Perguruan Tinggi adalah salah satu cara yang paling efektif untuk meningkatkan performa Perguruan Tinggi.Tujuan penelitian ini antara lain : (1) Melakukan identifikasi sejauh mana STIKES Muhammadiyah Samarinda dapat menerapkan Sistem Computer-Based Test (CBT) dalam seleksi mahasiswa baru. (2) Membuat suatu usulan solusi perencanaan strategis SI/TI dalam menerapkan Sistem Computer-Based Test (CBT) menggunakan Metode Ward and Peppard. (3) Menganalisis tingkat pelayanan sistem Computer Based Test (CBT) dalam seleksi penerimaan mahasiswa baru yang sudah berjalan.

\section{METODE PENELITIAN}

\subsection{Perencanaan Strategis SI/TI Versi Ward and Peppard}

Pendekatan metodologi ini dimulai dari kondisi investasi SI/TI dimasa lalu yang kurang sejalan dengan tujuan bisnis organisasi dan kurang cepat dalam menangkap peluang bisnis, serta tidak memiliki keunggulan kompetitif. Ini terjadi karena suatu organisasi kurang mampu memanfaatkan SI/TI dengan maksimal. Kurang bermanfaatnya investasi SI/TI bagi organisasi disebabkan karena perencanaan strategi SI/TI yang lebih fokus ke teknologi, bukan berdasarkan kebutuhan bisnis. 


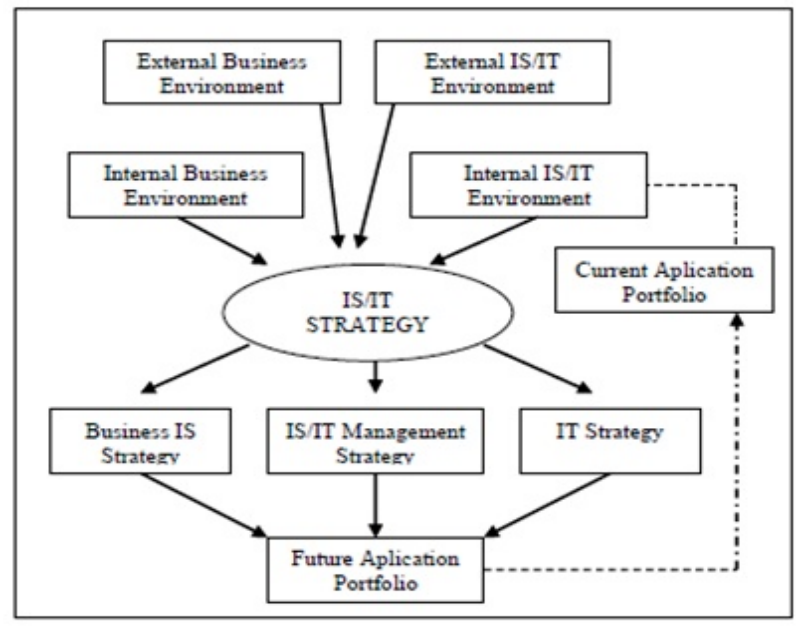

Gambar 1. Model Perencanaan Strategis SI/TI (Ward dan Peppard, 2002)

Metodologi versi ini terdiri dari tahapan masukan dan tahapan keluaran (Ward dan Peppard, 2002:187). Tahapan masukan terdiri dari :

1. Analisis lingkungan bisnis internal, yang mencakup aspek-aspek strategi bisnis saat ini, sasaran, sumber daya, proses, serta budaya nilai-nilai bisnis organisasi.

2. Analisis lingkungan bisnis eksternal, yang mencakup aspek-aspek ekonomi, industri, dan iklim bersaing perusahaan.

3. Analisis lingkungan SI/TI internal, yang mencakup kondisi SI/TI organisasi dari perspektif bisnis saat ini, bagaimana kematangannya (maturity), bagaimana kontribusi terhadap bisnis, ketrampilan sumber daya manusia, sumber daya dan infrastruktur teknologi, termasuk juga bagaimana portofolio dari SI/TI yang ada saat ini.

4. Analisis lingkungan SI/TI eksternal, yang mencakup tren teknologi dan peluang pemanfaatannya, serta penggunaan SI/TI oleh kompetitor, pelanggan dan pemasok.

Sedangkan tahapan keluaran merupakan kegiatan yang dilakukan untuk menghasilkan suatu dokumen perencanaan strategis SI/TI yang isinya terdiri dari:

1. Strategi SI bisnis, yang mencakup bagaimana setiap unit/fungsi bisnis akan memanfaatkan SI/TI untuk mencapai sasaran bisnisnya, portofolio aplikasi dan gambaran arsitektur informasi.

2. Strategi TI, yang mencakup kebijakan dan strategi bagi pengelolaan teknologi dan sumber daya manusia SI/TI.

3. Strategi Manajemen SI/TI, yang mencakup rencana Penerapan SDM elemen-elemen umum yang diterapkan melalui organisasi, untuk memastikan konsistensi penerapan kebijakan SI/TI yang dibutuhkan

Beberapa teknik/metode analisis yang digunakan dalam perencanaan strategis SI/TI pada metodologi ini, mencakup analisis PEST, SWOT, analisis Five Forces Competitive, analisis Value Chain, metode Critical Succes Factors, dan McFarlan's Strategic Grid.

\subsection{Metode}

Metode yang digunakan berdasarkan permasalahan yang ada pada penerapan sistem Computer Based-Test(CBT), maka penelitian dilakukan secara bertahap dengan mengacu pada metodologi Ward \& Peppard (2002) dengan tahapan penelitian seperti pada gambar 2.Berikut: 
Computatio: Journal of Computer Science and Information Systems, volume 1, no 2, Oktober 2017

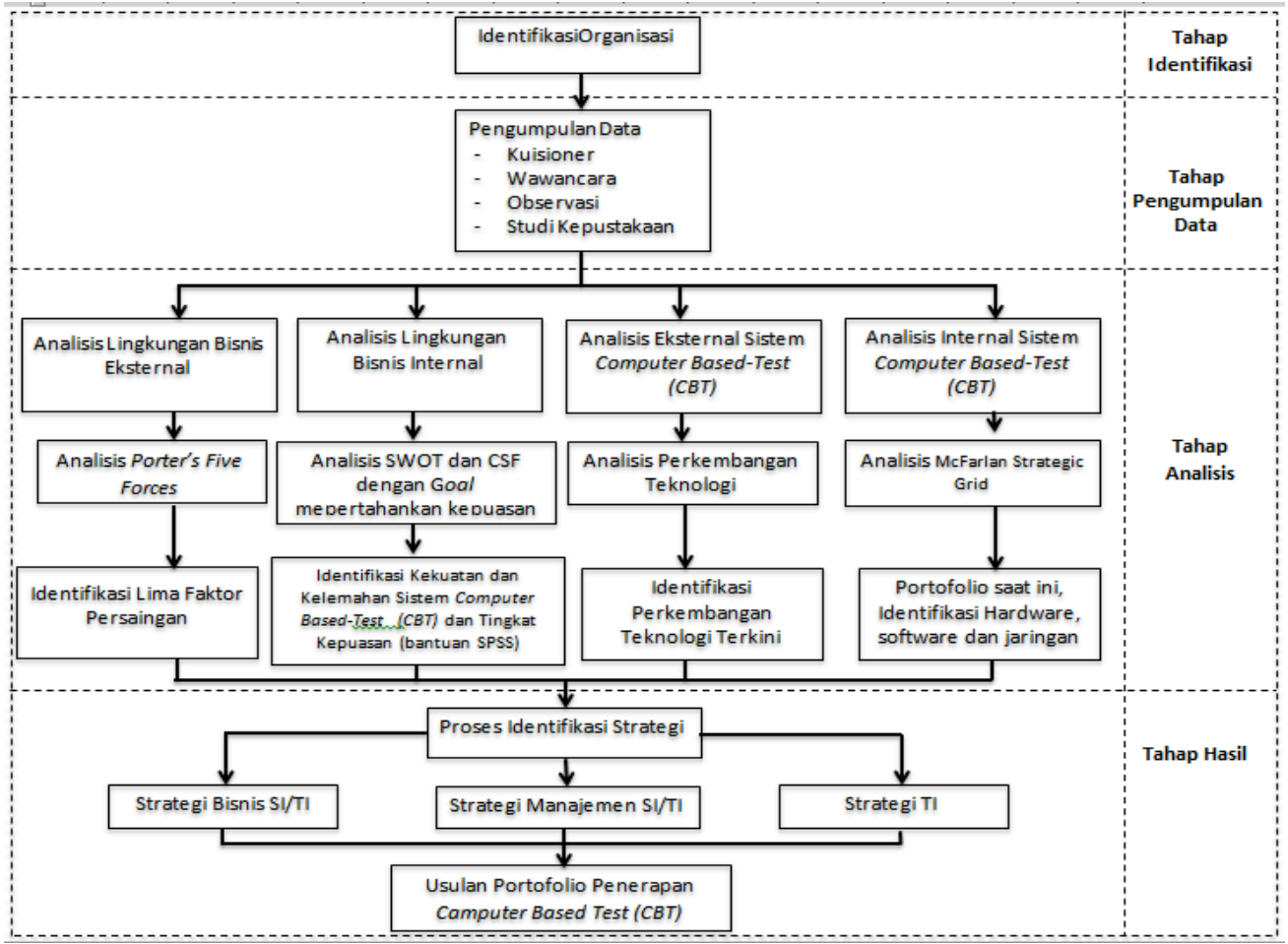

Gambar 2 Alur Penelitian

Pada tahapan analisis ini terdiri dari:

1. Tahap identifikasi organisasi

2. Tahap pengumpulan data antara lain kuisioner, wawancara, observasi dan studi kepustakaan

- Tahap analisis, yang meliputi analisis lingkungan eksternal, analisis lingkungan internal, analisis eksternal sistem Computer Based-Test (CBT), dan analisis internal sistem Computer Based-Test (CBT)

3. Tahap hasil

- Penentuan strategi bisnis SI/TI, penentuan strategi manajemen SI/TI, penentuan strategi TI, dan Usulan portofolio aplikasi

\subsection{Service Quality (Serqual)}

Untuk menganalisis kualitas jasa dapat dilakukan dengan mengkuantifikasi dimensi kualitas dengan menggunakan skala Likert pada kuesioner yang disebarkan kepada responden. Zeithaml, dkk. (1988) mengukur kualitas jasa dengan mengetahui perbedaan/gap antara harapan dengan persepsi pelanggan. Hal ini sesuai dengan definisi kualitas pelayanan, yaitu derajat perbedaan antara harapan pelanggan dengan persepsi pelanggan terhadap kinerja jasa yang diterimanya.

Dari uraian tersebut, peneliti mengemukakan hipotesis, bahwa terdapat hubungan positif antara gap (selisih antara kinerja kualitas jasa yang dipersepsikan dengan kualitas jasa yang diharapkan oleh calon mahasiswa) kualitas jasa, dengan kepuasan mahasiswa. Secara terperinci, beberapa hipotesis yang dapat dikemukakan adalah:

H1 : Apabila gap reliability semakin tinggi, maka kepuasan mahasiswa akan meningkat.

$\mathrm{H} 2$ : Apabila gap responsiveness semakin tinggi, maka kepuasan mahasiswa akan meningkat.

H3 : Apabila gap assurance semakin tinggi, maka kepuasan mahasiswa akan meningkat.

H4 : Apabila gap emphaty semakin tinggi, maka kepuasan mahasiswa akan meningkat.

H5 : Apabila gap tangible semakin tinggi, maka kepuasan mahasiswa akan meningkat. 
Model Service Quality didasarkan pada asumsi bahwa konsumen membandingkan kinerja jasa pada atribut-atribut relevan dengan standart ideal/sempurna untuk masingmasing atribut jasa. Penilaian kualitas jasa menggunakan model Servqual mencakup perhitungan perbedaan diantara nilai yang diberikan pada pelanggan untuk setiap pasang pertanyaan berkaitan dengan harapan dan persepsi.

Skor service quality untuk setiap pasang pertanyaan bagi masing-masing pelanggan dapat dihitung berdasarkan rumus berikut ( Tjiptono $2005: 275$ ) :

Skor servqual $=$ Skor persepsi - Skor Harapan

Pengukuran hasil survei dapat dilakukan dengan membandingkan anatara rata-rata harapan dengan persepsi dan tiap butir instrumen. Dengan demikian akan didapatkan Gap /kesenjangan, yaitu selisih kenyataan dan harapan. Hasil > - 1 (ex: -0, 40) berarti baik; dan hasil $<-1$ (ex: -1, 20) berarti kurang baik. Pada prinsipnya data yang diperoleh melalui instrumen Servqual dapat dipergunakan untuk menghitung skor gap kualitas jasa pada level secara rinci:

a. item-by-item analisys, missal $\mathrm{P} 1-\mathrm{H} 1, \mathrm{P} 2-\mathrm{H} 2$, dst.

b. Dimensi-by-dimensionalisys, contoh: $(\mathrm{P} 1+\mathrm{P} 2+\mathrm{P} 3+\mathrm{P} 4 / 4)-(\mathrm{H} 1+\mathrm{H} 2+\mathrm{H} 3+\mathrm{H} 4 / 4)$

dimana P1 sampai P4 dan H1 sampai H4 mencerminkan 4 pernyataan persepsi dan harapan berkaitan dengan dimensi tertentu.

c. Perhitungan ukuran tunggal kualitas jasa / Gap Servqual yaitu $(\mathrm{P} 1+\mathrm{P} 2+\mathrm{P} 3 \ldots . .+\mathrm{P} 22$ / $22)-(\mathrm{H} 1+\mathrm{H} 2+\mathrm{H} 3+\ldots . .+\mathrm{H} 22 / 22)$

d. Untuk menganalisis kualitas akan jasa pelayanan yang telah diberikan, maka digunakan rumus:

Kualitas $(Q) ? \frac{\text { Presepsi }(P)}{\text { Harapan }(H)}$

Jika kualitas $(\mathrm{Q})=1$, maka kualitas pelayanan dikatakan baik.

\section{HASIL DAN PEMBAHASAN}

\subsection{Analisis lingkungan Internal bisnis organisasi}

Pengidentifikasian berbagai faktor internal untuk membuat strategi organisasi dalam penelitian ini adalah menggunakan analisis SWOT, Critical Success factor's dengan kepuasan peserta (service quality).

\subsubsection{Analisis SWOT}

Tabel 1 Analisis SWOT

\begin{tabular}{ll}
\hline Kekuatan $($ Strength $)$ \\
\hline 1. & Soal diacak dapat menghindari menyontek masing-masing peserta dengan soal yang \\
berbeda. & \\
2. & Mengurangi waktu untuk pekerjaan koreksi penilaian tes dan membuat laporan tertulis \\
3. Menghilangkan pekerjaan logistik seperti mendistribusikan soal dan menyimpan dalam \\
bentuk kertas \\
4. Peserta tes dapat langsung mengetahui hasil tes
\end{tabular}


Computatio: Journal of Computer Science and Information Systems, volume 1, no 2, Oktober 2017

\begin{tabular}{ll}
\hline Kelemahan (Weakness) \\
\hline 1. & Server komputer yang bermasalah sehingga tidak dapat masuk ke sistem \\
2. & Client bermasalah tidak terkoneksi ke server \\
3. & Spesifikasi hardware yang sudah usang memperlambat keneksi \\
4. & Soal tidak up todate \\
5. & Peserta tes belum terbiasa atau belum familiar \\
\hline Peluang (Opportunity) & Melihat perkembangan SI/TI saat ini, penerapan sistem Computer Based-Test (CBT) \\
\hline 1. & adalah sebagai jawaban dalam seleksi mahasiswa baru \\
2. & Calon maasiswa banyak berasal berbagai daerah di kaltim sebagai peluang dalam \\
& penerapan sistem Computer Based-Test (CBT) di luar kampus \\
3. & Memiliki jaringan WAN dalam koneksi sistem Computer Based-Test (CBT) didukung \\
& dengan bandwith Internet yang memadahi \\
\hline Ancaman (Threat) & Keamanan data terhadap virus \\
1. & Listrik tidak stabil sering terjadi pemadaman \\
3. & Kompetitor menggunakan sistem yang sama \\
4. & Ketika Kompetitor biaya pendaftaran bersaing \\
\hline
\end{tabular}

\subsubsection{Analisis Critical Succes Factor(CSF)}

Analisis Critical Succes Factor(CSF) merupakan analisis terhadap factor-faktor penting yang harus diperhatikan untuk menentukan kesuksesan penerapan sisitem Computer Based-Test $(C B T)$. Dalam hal ini faktor untuk menentukan kesuksesan penerapan sistem tersebut dengan mengetahui tingkat kepuasan perserta yang mengikuti tes seleksi mahasiswa baru menggunakan sistem Computer Based-Test (CBT).

Tabel 2 Pemetaan Tujuan Bisnis CSF Permasalahan dan solusi

\begin{tabular}{|c|c|c|c|}
\hline Tujuan Bisnis & CSF & Permasalahan & Alternatif Solusi \\
\hline $\begin{array}{l}\text { Mengoptimalkan } \\
\text { penerapan sistem } \\
\text { Computer Based- } \\
\text { Test (CBT) dalam } \\
\text { seleksi mahasiswa } \\
\text { baru }\end{array}$ & $\begin{array}{ll}- & \text { Sistem Computer } \\
& \text { Based-Test }(C B T) \\
- & \text { Sistem pendaftaran } \\
\text { online }\end{array}$ & $\begin{array}{l}\text { - Sistem Computer } \\
\text { Based-Test (CBT) } \\
\text { masih bersifat } \\
\text { LAN, lokal areal } \\
\text { kampus } \\
\text { - Pendataran } \\
\text { mahasiswa baru } \\
\text { banyak yang } \\
\text { manual }\end{array}$ & $\begin{array}{l}\text { - Mengembangkan } \\
\text { jaringan sistem } \\
\text { Computer Based-Test } \\
\text { (CBT) menjadi WAN } \\
\text { - Membuka pendaftaran } \\
\text { mahasiswa baru di luar } \\
\text { kampus } \\
\text { - Memaksimalkan Sistem } \\
\text { pendaftaran online yang } \\
\text { berada di website dan } \\
\text { tidak melayani yang } \\
\text { manual }\end{array}$ \\
\hline
\end{tabular}

3.1.3 Analisis data Kuesioner tingkat kepuasan peserta tes terhadap sistem Computer BasedTest (CBT)

Analisis kuesioner dalam penelitian ini sampel yang diambil dari lingkungan penerimaan mahasiswa baru di STIKES Muhammadiyah Samarinda tahun ajaran 2016/2017 dengan keterbatasaan waktu yang dilaksanakan dari bulan Maret 2016 sampai dengan April 2016 menggunakan 38 responden, 3data responden rusak menjadi 35 responden.

Data yang diperoleh melalui kuesioner yang diisi oleh responden menunjukan bahwa frekuensi responden pria sebesar 12 orang dengan presentase 34,3\%. Frekuensi responden 
wanita sebesar 23 orang dengan presentase $65,7 \%$. Jadi dapat disimpulkan bahwa mayoritas responden dalam penelitian ini adalah perempuan.

Penyajian Data Dimensi Servqual

Berikut ini adalah pembahasan score servqual yang dapat dilihat pada uraian pembahasan perdimensi servqual berdasarkan analisis data kesenjangan (gap) antara harapan (expectations) dengan persepsi (perceptions).

Dimensi Bukti Langsung (tangible)

Tabel 3 Dimensi Bukti Langsung

\begin{tabular}{llccc}
\hline No & \multicolumn{1}{c}{ Pertanyaan } & Harapan & Presepsi & Gap \\
\hline 1. & $\begin{array}{l}\text { Kenyamanan kebersihan, kerapian dan tata letak } \\
\text { ruang tempat sistem Computer Based-Test(CBT) }\end{array}$ & 4,74 & 4,20 & $-0,54$ \\
2. $\quad \begin{array}{l}\text { Kenyamanan fasilitas yang di berikan meja dan } \\
\text { tempat duduk dalam ruang sistem Computer }\end{array}$ & 4,68 & 4,42 & $-0,26$ \\
$\quad \begin{array}{l}\text { Based-Test(CBT) } \\
\text { Penerangan cukup di ruang tempat sistem }\end{array}$ & 4,74 & 4,23 & $-0,51$ \\
$\quad \begin{array}{l}\text { Computer Based-Test(CBT) } \\
\text { Kenyamanan suhu di ruang tempat sistem }\end{array}$ & 4,71 & 4,28 & $-0,43$ \\
$\quad \begin{array}{l}\text { Computer Based-Test(CBT) } \\
\text { Kerapian petugas dalam penampilan }\end{array}$ & 4,66 & 4,34 & 0,32 \\
\hline Rata-Rata (Mean) & 4,70 & 4,29 & $-0,41$ \\
\hline Kualitas (Q) = Persepsi (P) / Harapan (E) & & 0,91 & \\
\hline
\end{tabular}

Secara garis besar dari dimensi bukti langsung (tangible), kualitas pelayanan yang telah diberikan bernilai positif $(+)$ yaitu sebesar 0,91 sehingga kualitas jasa dikategorikan baik (peserta sangat puas).

Dimensi Keandalan (reliability)

Tabel 4 Dimensi Keandalan

\begin{tabular}{llccc}
\hline No & \multicolumn{1}{c}{ Pertanyaan } & Harapan & Presepsi & Gap \\
\hline 6. & $\begin{array}{l}\text { Petugas memastikan anda dapat masuk/menggunakan } \\
\text { (login) ke sistem Computer Based-Test (CBT) }\end{array}$ & 4,86 & 4,31 & $-0,55$ \\
7. $\quad \begin{array}{l}\text { Kemudahan pengoperasian sistem Computer Based- } \\
\quad \text { Test (CBT) }\end{array}$ & 4,80 & 4,40 & $-0,40$ \\
8. $\quad \begin{array}{l}\text { Kemudahan memahami materi soal di sistem } \\
\quad \begin{array}{l}\text { Computer Based-Test (CBT) } \\
\text { Ketersediaan fasilitas pendukung (hardware dan }\end{array}\end{array}$ & 4,37 & 3,80 & $-0,43$ \\
9oftware) ketika tes berlangsung & 4,71 & $-0,63$ \\
10. $\quad \begin{array}{l}\text { Hasil/skor yang langsung dapat diketahui setelah } \\
\text { selesai tes di sistem Computer Based-Test (CBT) }\end{array}$ & 4,77 & 4,37 & $-0,40$ \\
\hline Rata-Rata (Mean) & 4,70 & 4,20 & $-0,48$ \\
\hline Kualitas (Q) =Persepsi (P)/Harapan (E) & & 0,89 & \\
\hline
\end{tabular}

Secara garis besar dari dimensi keandalan (reliability), kualitas pelayanan yang telah diberikan bernilai positif $(+)$ yaitu sebesar 0,89 sehingga kualitas jasa dikategorikan baik (peserta sangat puas).

Dimensi Daya Tanggap (responsiveness) 
Computatio: Journal of Computer Science and Information Systems, volume 1, no 2, Oktober 2017

Tabel 5 Dimensi Daya Tanggap

\begin{tabular}{llccc}
\hline No & \multicolumn{1}{c}{ Pertanyaan } & Harapan & Presepsi & Gap \\
\hline 11. & $\begin{array}{l}\text { Kesigapan petugas langsung memberikan bantuan } \\
\text { ketika terjadi masalah }\end{array}$ & 4,80 & 4,46 & $-0,34$ \\
12. & $\begin{array}{l}\text { Waktu yang fleksibel yang diberikan petugas dalam } \\
\text { pelaksanaan tes di sistem Computer Based-Test }(C B T)\end{array}$ & 4,57 & 4,08 & $-0,49$ \\
13. $\quad$ Ketersedian petunjuk operasional bagi peserta tes & 4,68 & 4,14 & $-0,54$ \\
14. $\quad \begin{array}{l}\text { Kecepatan petugas dalam memberikan pelayanan } \\
\quad \text { setelah sesi pergantian peserta tes }\end{array}$ & 4,60 & 4,26 & $-0,34$ \\
15. & $\begin{array}{l}\text { Petugas menanggapi setiap pertanyaan dari peserta } \\
\quad \text { ujian dengan baik }\end{array}$ & 4,77 & 4,14 & $-0,63$ \\
Rata-Rata (Mean) & 4,68 & 4,21 & $-0,47$ \\
\hline Kualitas (Q) = Persepsi (P)/Harapan (E) & & 0,90 & \\
\hline
\end{tabular}

Secara garis besar dari dimensi daya tanggap (responsiveness), kualitas pelayanan yang telah diberikan bernilai positif $(+)$ yaitu sebesar 0,90 sehingga kualitas jasa dikategorikan baik (peserta sangat puas)

Dimensi Jaminan (assurance)

Tabel 6 Dimensi Jaminan

\begin{tabular}{lllcc}
\hline No & \multicolumn{1}{c}{ Pertanyaan } & Harapan & Presepsi & Gap \\
\hline 16. & $\begin{array}{l}\text { Pengetahuan petugas dalam memberikan informasi } \\
\text { penggunaan sistem Computer Based-Test (CBT) }\end{array}$ & 4,74 & 4,26 & $-0,48$ \\
17. & $\begin{array}{l}\text { Kemampuan petugas dalam menyelesaikan } \\
\text { permasalahan yang terjadi pada saat tes berlangsung }\end{array}$ & 4,68 & 4,14 & $-0,54$ \\
18. $\quad$ Kesopanan petugas dalam melayani & 4,88 & 4,63 & $-0,25$ \\
$19 \quad \begin{array}{l}\text { Tidak akan ada kecurangan hasil/skor ujian dengan } \\
\text { sistem Computer Based-Test (CBT) }\end{array}$ & 4,77 & 4,51 & $-0,26$ \\
20. $\quad \begin{array}{l}\text { Keamanan bahaya arus lisrik dan antisipasi terhadap } \\
\text { mati listrik dari PLN }\end{array}$ & 4,74 & 4,23 & $-0,51$ \\
\hline Rata-Rata (Mean) & 4,78 & 4,35 & $-0,41$ \\
\hline Kualitas (Q) = Persepsi (P)/Harapan (E) & & 0,91 & \\
\hline
\end{tabular}

Secara garis besar dari dimensi jaminan (assurance), kualitas pelayanan yang telah diberikan bernilai positif $(+)$ yaitu sebesar 0,91 sehingga kualitas jasa dikategorikan baik (peserta sangat puas).

Dimensi Empati (empathy)

Tabel 7 Dimensi Empati

\begin{tabular}{|c|c|c|c|c|}
\hline No & Pertanyaan & Harapan & Presepsi & Gap \\
\hline 21. & $\begin{array}{l}\text { Kemudahan menghubungi petugas ketika terjadi } \\
\text { permasalahan }\end{array}$ & 4,80 & 4,28 & $-0,52$ \\
\hline 22. & Komunikasi yang baik dengan petugas & 4,68 & 4,31 & $-0,37$ \\
\hline 23. & $\begin{array}{l}\text { Keluhan dan saran ditanggapi dengan baik oleh } \\
\text { petugas }\end{array}$ & 4,77 & 4,26 & $-0,51$ \\
\hline 24. & $\begin{array}{l}\text { Perhatian petugas pada kebutuhan-kebutuhan } \\
\text { peserta ujian }\end{array}$ & 4,71 & 4,34 & $-0,37$ \\
\hline 25. & $\begin{array}{l}\text { Petugas memberikan semangat dan motivasi bagi } \\
\text { peserta yang belum berhasil }\end{array}$ & 4,74 & 4,00 & $-0,74$ \\
\hline \multicolumn{2}{|r|}{ Rata-Rata (Mean) } & 4,74 & 4,23 & $-0,50$ \\
\hline \multicolumn{2}{|c|}{ Kualitas $(\mathrm{Q})=$ Persepsi $(\mathrm{P}) /$ Harapan $(\mathrm{E})$} & & 0,89 & \\
\hline
\end{tabular}


Secara garis besar dari dimensi empati (empathy), kualitas pelayanan yang telah diberikan bernilai positif $(+)$ yaitu sebesar 0,89 sehingga kualitas jasa dikategorikan baik (peserta sangat puas).

\subsection{Analisis Lingkungan Eksternal bisnis organisasi}

\subsubsection{Analisis Lima Faktor Persaingan Porter (Porter's Five Forces)}

Model lima faktor persaingan Porter (Porter's Five Forces) digunakan untuk menganalisa kondisi lingkungan eksternal yang dihadapi oleh STIKES Muhammadiyah Samarinda. Kekuatan Lima Persaingan Porter yang ada di STIKES Muhammadiyah Samarinda dapat dilihat melalui gambar berikut:

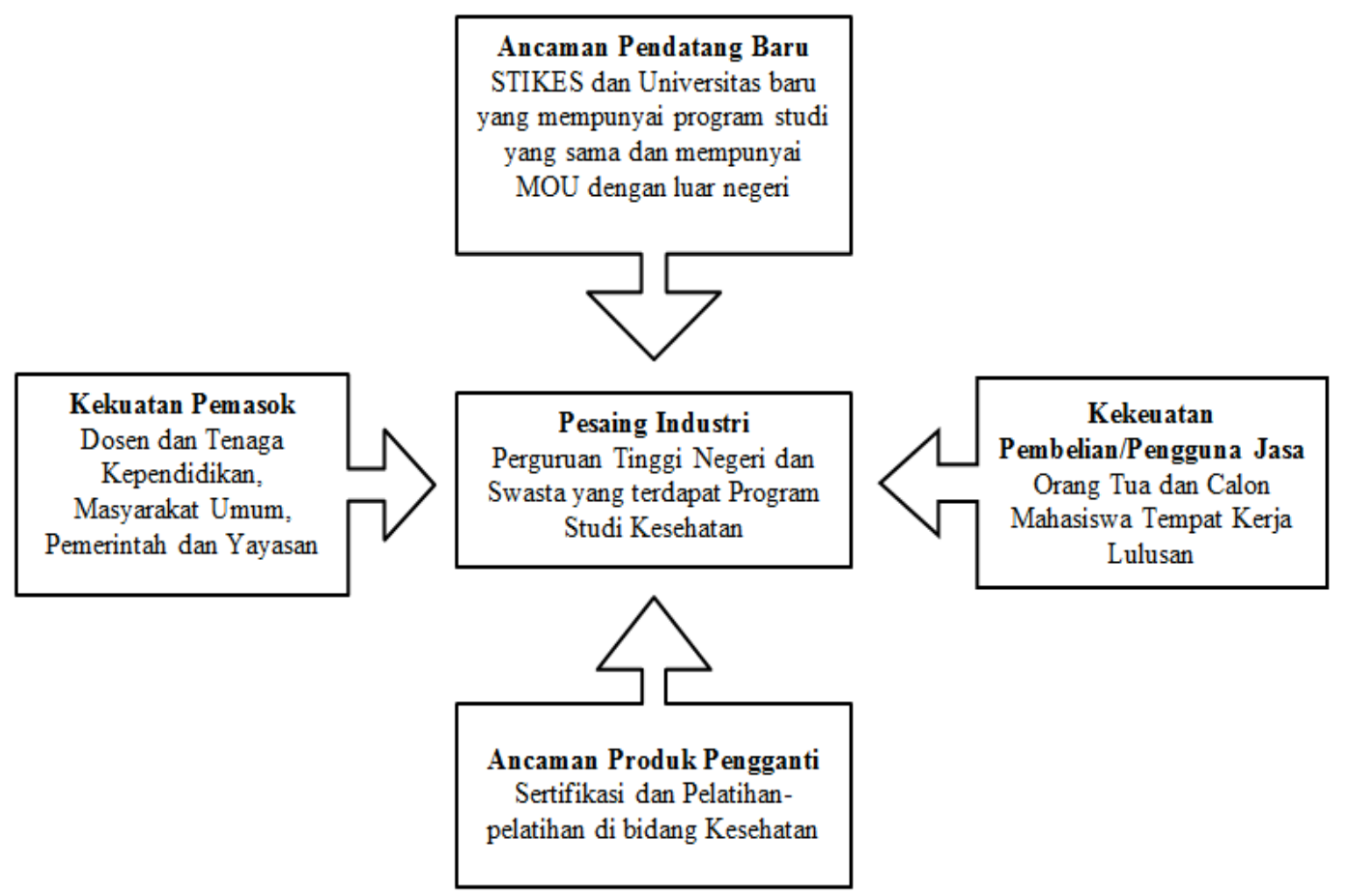

Gambar 5. Porter's Five Forces STIKES Muhammadiyah Samarinda

\subsection{Analisis Internal Sistem Computer Based-Test (CBT)}

Analisis aset SI/TI yang ada pada sistem Computer Based-Test(CBT) saat ini, dikelompokkan berdasarkan hardware dan software yang digunakan untuk menunjang keberlangsungan bisnis proses seleksi penerimaan mahasiswa baru saat ini yang ada di STIKES Muhammadiyah Samarinda.

\subsubsection{Analisis Portofolio Aplikasi McFarlan}

Portofolio aplikasi yang ada saat ini menggunakan strategi McFarlan yang berguna untuk analisis yang menghasilkan nilai aplikasi yang digunakan STIKES Muhammadiyah Samarinda dalam penerimaan mahasiswa baru. Analisis ini untuk mengetahui nilai aplikasi masuk dalam kategori high potential, strategic, key operational, atau support yang sesuai dengan kontribusi yang ada pada sistem Computer Based-Test(CBT).

Portofolio aplikasi mendatang yang mengacu pada portofolio aplikasi yang ada saat ini berdasarkan hasil analisis internal IS/IT maka dapat dipetakan aplikasi-aplikasi yang mendukung dalam penerimaan mahasiswa baru di STIKES Muhammadiyah Samarinda menggunakan Matriks McFarlan sebagai berikut: 
Tabel 8 Portfolio aplikasi saat ini

\begin{tabular}{lll}
\hline & \multicolumn{1}{c}{ Strategic } & \multicolumn{1}{c}{ Higt Potential } \\
\hline- & \multicolumn{1}{c}{ Sistem Computer Based-Test } \\
(CBT) & & \\
\hline - $\begin{array}{l}\text { Sistem Informasi Akademik } \\
\text { (SIKAD) }\end{array}$ & & $\begin{array}{l}\text { Website STIKES Muhamamdiyah } \\
\text { Samarinda }\end{array}$ \\
- $\begin{array}{l}\text { Sistem pendaftaran online } \\
\text { berbasis web }\end{array}$ & \\
\hline \multicolumn{1}{c}{ Key Operational } & \multicolumn{1}{c}{ Support } \\
\hline
\end{tabular}

3.4 Analisis Eksternal Sistem Computer Based-Test(CBT)

Analisis lngkungan eksternal ini berguna untuk mengetahui trend sistem dan teknologi informasi yang sedang berkembang dan banyak digunakan saat ini. Menurut Gartner dalam Top 10 Technology Trends for 2016 bahwa ada 10 tren teknologi yang paling berpengaruh di dunia terhadap individu, bisnis dan organisasi saat ini, yakni: The Device Mesh, Ambient User Experience, 3D-printing Materials, Information of Everything, Advanced Machine Learning, Autonomous Agents and Things, Advanced Security Architecture, Advanced Customer Architecture, Mesh App and Sevice Architecture, Internet of Things Architecture and Platforms.

\subsection{Menentukan Strategi}

\subsubsection{Strategi Bisnis SI/TI}

Strategi bisnis SI adalah strategi yang dilakukan untuk menjelaskan apakah sistem dan teknologi informasi dapat mendukung kegiatan dalam penerimaan mahasiswa baru. Strategi bisnis ini juga disesuaikan dengan fungsi bisnis yang ada di perguruan tinggi.

\subsubsection{Pengembangan sistem informasi yang ada}

Sistem seleksi Penerimaan Mahasiswa Baru dalam hal ini sistem Computer BasedTest $(C B T)$, perlu dilakukan ekstensifikasi dalam bentuk web-based sehingga bisa di akses di tempat lain untuk mengakomodasi kebutuhan seleksi yang berada di luar kota Samarinda, maka perlu dibuat modul sistem Computer Based-Test(CBT)

\subsubsection{Strategi Manajemen SI/TI}

Strategi manajemen SI/TI diperoleh dari hasil identifikasi solusi SI/TI sehingga dibutuhkan rekrutmen SDM pada struktur organisasi Unit IT. Strategi manajemen SI/TI disini merupakan kebijakan yang diambil oleh pihak manajemen terkait dengan SI/TI yang akan dikembangkan dan diimplementasikan. Kebijakan tersebut diwujudkan dengan menambahkan personil ke dalam struktur organisasi yang ada sehingga dapat mendukung SI/TI perguruan tinggi dalam pengambilan keputusan demi mencapai tujuan.

\subsubsection{Strategi TI}

Strategi TI ini menjawab harapan reponden yaitu Ketua STIKES Muhammadiyah Samarinda mengenai teknologi yang akan berubah dan apa yang menyebabkan dasar perubahan tersebut. Dalam hal ini perubahan kearah pengembangan jaringan sistem Computer BasedTest(CBT) dimaksudkan agar proses seleksi mahasiswa baru di luar areal kampus supaya terselenggara. Usulan rekomendasi mencakup perubahan pada struktur jaringan dan penambahan beberapa hardware untuk dapat mendukung sistem yang diusulkan. 
3.5.4 Portofolio Usulan Aplikasi yang akan datang yang mendukung penerimaan mahasiswa baru

Setelah dilakukan identifikasi seluruh solusi, maka selanjutnya solusi-solusi tersebut digambarkan dalam matriks portofolio McFarlan. Portofolio aplikasi ini akan memperlihatkan analisis dari aplikasi-aplikasi yang mendukung penerimaan mahasiswa baru STIKES Muhammadiyah Samarinda yang ada saat ini dan usulan aplikasi yang mendukungpenerimaan mahasiswa baru. Portofolio aplikasi yang akan datang dapat dilihat pada tabel 3 dibawah ini.

Tabel 9 Usulan Portfolio

\begin{tabular}{|c|c|c|c|}
\hline \multicolumn{2}{|l|}{ Strategic } & \multicolumn{2}{|l|}{ Higt Potential } \\
\hline $\begin{array}{l}\text { Adanya Pendaftaran Mahasiswa } \\
\text { Baru } \\
\text { Adanya tes seleksi penerimaan } \\
\text { mahasiswa baru } \\
\text { Penyelanggaraan pendaftaran dan } \\
\text { tes seleksi mahasiswa baru di luar } \\
\text { kota }\end{array}$ & $\begin{array}{l}\text { Ada } \\
\text { Ada } \\
\text { Baru }\end{array}$ & $\begin{array}{l}\text { Website STIKES } \\
\text { Muhamamdiyah } \\
\text { Samarinda fasilitas } \\
\text { pendaftaran online } \\
\text { - Sistem Computer } \\
\text { Based-Test (CBT) } \\
\text { berbasis WAN }\end{array}$ & $\begin{array}{l}\text { Ada } \\
\text { (upgrade) } \\
\text { Baru }\end{array}$ \\
\hline $\begin{array}{l}\text { Sistem pendaftaran online berbasis } \\
\text { web } \\
\text { - Sistem Sistem Informasi Akademik } \\
\text { - Seleksi Mahasiswa Baru dengan } \\
\text { sistem Computer Based-Test (CBT) } \\
\text { - Pengembangan jaringan sistem } \\
\text { Computer Based-Test (CBT) dari } \\
\text { LAN menjadi WAN }\end{array}$ & $\begin{array}{l}\text { Ada } \\
\text { Ada } \\
\text { (upgrade) } \\
\text { Baru }\end{array}$ & $\begin{array}{l}\text { - Sistem informasi } \\
\text { Promosi dan publikasi }\end{array}$ & Baru \\
\hline Key Operational & & Support & \\
\hline
\end{tabular}

\section{KESIMPULAN}

Dari hasil penelitian dan analisis yang telah dilakukan, maka dapat diambil kesimpulan sebagai berikut:

1. Penerapan sistem Computer-Based Test (CBT) ) pada penerimaan mahasiswa baru di STIKES Samarinda, masih sebatas jarinngan LAN sedangkan calon pendaftar mahasiswa baru banyak dari luar kota Samarinda di wilayah Kalimantan Timur.

2. Telah dihasilkan perencanaan strategi penerapan sistem Computer-Based Test (CBT) pada penerimaan mahasiswa baru di Sekolah Tinggi Ilmu Kesehatan Muhammadiyah Samarinda yang meliputi: Strategi Bisnis SI/TI, Strategi TI dan Strategi Manajemen SI/TI.

3. Solusi strategi penerapan sistem Computer-Based Test (CBT) yang dihasilkan dirancang menggunakan framework Ward \& Peppard yang meliputi analisis lingkungan internal dan eksternal bisnis serta analisis lingkungan internal dan eksternal penerapan sistem Computer-Based Test (CBT) yang berdasarkan strategi bisnis STIKES Muhammadiyah Samarinda, yaitu meningkatkan pelayanan dalam seleksi mahasiswa baru.

4. Dari setiap solusi strategi penerapan sistem Computer-Based Test (CBT) dipetakan menjadi usulan portofolio aplikasi di masa mendatang, usulan perubahan teknologi berupa hardware dan software, usulan penambahan infrastruktur jaringan berupa WAN dan usulan kebutuhan sumber daya manusia.

5. Kualitas layanan penerapan sistem Computer-Based Test (CBT) di proyeksikan dalam 5 komponen yaitu Responsivness, Reliability, Assurance, Emphaty dan Tangibles. Dari 5 komponen tersebut bernilai positif $(+)$ sehingga kualitas jasa dikategorikan baik (peserta sangat puas). 
Computatio: Journal of Computer Science and Information Systems, volume 1, no 2, Oktober 2017

\section{DAFTAR PUSTAKA}

[1] Ward, J. \& Preppar, J. (2002). Strategic Planning for Information System (2nd ed.). John Wiley \& Sons.

[2] Zeithaml, A.V., Berry L.L. dan Parasuraman, A. (1988), 'Communication and Control Processes in the Delivery of Service Quality', Journal of Marketing, Vol. 52: 35-48.

[3] Zeithaml, A. V. Parasuraman and Leonard, L. B. (1988). SERVQUAL : A Multiple-Item Scale For Measuring Customer Perceptions of Service Quality, Journal of Retailing, 64, pp. 12-23.

[4] Tjiptono, F. (2005). Prinsip-Prinsip Total Qualty Serice, Andi Offset.. 